\title{
Trends in the growth of net State Domestic Product in Karnataka
}

\author{
Dr. Sharmila.R \\ Assistant Professor, Faculty of Science and Humanities \\ M.S.Ramaiah University of Applied Sciences, Bangalore.
}

OScholedge International Journal of Management \& Development (ISSN 2394-3378), Vol.02, Issue 10 (2015) p-41-50. Published by: Scholedge R\&D Center [www.theSCHOLEDGE.org] [Email: sijmd@scholedge.org]

\begin{abstract}
Being eighth largest state in India (geographically), the involvement of Karnataka for India's rising success is significant. Diverse agricultural and mineral resources and strong manufacturing capabilities of Karnataka accounts for close to 10 per cent of India's product exports. The State's software exports are more than 35 per cent of India's software exports. Being the world's fourth largest technology cluster, Bangalore has the perfect ecosystem fostering growth and development of State-of-the-art technology. The State has made notable progress in all sectors inspite of the global slowdown in recent years. This paper is an attempt to analyse the trends in the growth of Net State Domestic Product in Karnataka for the period 1980-2011. It is concerned with the growth of different sectors of the economy, the changes in the shares of sectors to the Net State Domestic Product of Karnataka. The paper categorised a period of 31 years (1980-2011) as the Pre-liberalisation period-1980-1990, two phases of liberalisation:-Period/Phase 1:1990-2000, Period/Phase 2:2000-2011.Methodology follows the semi-log growth model. Karnataka recorded considerable growth rate of domestic product in the I-Phase and II-Phase of liberalisation period and for the entire period. What has been observed is that in the three periods and for the entire period both in terms of rates of growth and share in net state domestic product the tertiary sector has dominated.
\end{abstract}

Keywords: Gross Domestic Product, Karnataka Economy, Growth of different sectors, Shares of different Sectors, Pre-liberalisation period, Post-liberalisation period.

\section{- The Background}

Natural endowments and constraints, initial stages of development, mobility of resources, scale economies leading to specialisation and host of other factors influence development patterns of regions within the country. The pattern of growth across the states within India has been a subject of interest both to academics as well as policymakers. Scholars like Battacharya, B.B and S. Sakthivel (2001) Bhide, Shashanka et al (2005) Pillai, M. and N. Shanta (2005) Kumar A.T and Roy. S (2011) had examined the growth of State Domestic Product in depth.

Karnataka has been considered as a middle-income state in India. During the period 1980-83 to 2003-06 Karnataka registered a compound annual growth rate of 4.43 per cent which puts it among a few states which have recorded a growth rate of 4 per cent or more during this period. This statement clearly shows that Karnataka's economy has grown at a 
healthy rate during this period (Shiddalingaswami $\mathrm{H}$ and Raghavendra $\mathrm{V} \mathrm{K}$ 2010). The state could not achieve the targeted growth during the $11^{\text {th }}$ Five Year Plan due to uncertain and challenging global and national situations along with the drought condition. However, in 2013-14, Karnataka's Gross State Domestic Product (GSDP) at constant (2004-05) price reached Rs. 311628 crores. The agriculture and allied sector has grown by 3.6 per cent in 2013-14 as against a negative growth of (-) 4.9 per cent during 2012-13. The industry sector has grown at 1.2 per cent during 2013-14.

A declining growth rate of the service sector from 8.4 per cent in 2012- 13 to 7.2 per cent in 2013-14 is noticed. However, Real Estate, Ownership of Dwellings and Business Services, Public Administration and Other Services have each grown by more than 9 per cent, which is a key driver of the 5.0 per cent growth of GSDP in 2013-14.Nevertheless, the Government is optimistic about the 12th Five Year Plan, during which the State Government aims to strengthen the strategy and achievements made in the previous plan period by intensifying government reforms, ensuring effective targeting of subsidies and better monitoring, and instituting a process of informed decision making through independent evaluation. Being one of the fastest growing states in India the state has a strong industrial base and energetic tertiary sector. It is the services sector, has in fact been, the engine of growth (Economic Survey of Karnataka 2013-14).

With this backdrop, the present paper has been undertaken. Section 1 begins with conceptual framework. Section 2 proceeds with comparative analysis of overall growth rate of NSDP of different states with growth performance of Karnataka. The rationale being selection of the states for comparative analysis is based on their contribution to the national output, employment and exports. Section 3 deals with the sectoral growth rates in the Net State Domestic Product (NSDP) in Karnataka, their share in Net State Domestic Product in Karnataka and the broad conclusions emerging therefrom.

\section{- Conceptual Framework}

State income, fiscal deficit and public debt are the principal indicators of the performance of the state and involved in comparing the fiscal performance of the states. The estimate of state income is considered as an important measure of economic development of the state, and an important tool for planning. The aggregates of this estimate can be further broken down to obtain the sectoral estimates, their contributions, their growth etc. Long period of state income estimation shows the extent and direction of growth of a state, and sectoral composition represents relative position of the different sectors in the economy.

\section{- Data and Methodology}

The important issue in any study of the long-term trends is the choice of an appropriate base year; it should be a normal year and somewhere near the middle of the series. It does not seem appropriate to use the base year 2004-05 because the commodity composition and relevance of commodities may be changing over time. Hence the paper used 1993-94 as the base year for this analysis covering the period 1980-81 to 2000-2011. The periodical revision of base year for the estimation of State Domestic Product is difficult to combine the different series and work out the growth rate for a long term period. Besides, 
the revision of the methodology, concepts and the use of new sources of data etc from time to time and along with the base year changes results in significant differences between the estimates as per the old and new series. Therefore strict comparability of the different growth rates of State Domestic Product at constant prices are questionable and cautious interpretation is required. This point is particularly more important when the sectoral shifts in the State Domestic Product and the relative growth rates of sectoral State Domestic Product at constant prices are interpreted. It is for these reasons the paper developed a linked series for the analysis. For the compilation of a linked series splicing method has been used.

Source of the basic data used in this analysis has been the publications of Handbook of Statistics on Indian Economy various issues. Different methods have been used by different scholars for estimation of growth rate. The methods are ranging from average annual growth, and compound growth to exponential fit. In this paper the compound growth rate methodology has been used.

\section{- Inter-state Comparisons of Growth Performance Conceptual Framework}

With regard to inter-state comparison of growth performance, it can be observed from table 1 that there is variation in growth performance among the states in the sub periods, with some states growing faster than others, but the degree of dispersion in growth rates not increased significantly in all the periods. The growth rate of Net State Domestic Product of Karnataka is $\mathbf{5 . 2}$ per cent during the Pre-liberalisation period 1980-81 to 1989-90, approximately comparable to the growth rate of Net Domestic Product of India (5.3 per cent).

Table-1

Compound Growth Rate of Net State Domestic Product of Selected States (1993-94 prices)

\begin{tabular}{|c|c|c|c|c|}
\hline STATES & $\begin{array}{c}1980- \\
81- \\
1989- \\
90\end{array}$ & $\begin{array}{c}1990- \\
91- \\
1999- \\
00\end{array}$ & $\begin{array}{c}\text { 2000- } \\
\text { 01-2010- } \\
11\end{array}$ & $\begin{array}{c}1980- \\
81- \\
2010- \\
11\end{array}$ \\
\hline $\begin{array}{l}\text { ANDHRA } \\
\text { PRADESH }\end{array}$ & 5.2 & 5.2 & 8.2 & 6.2 \\
\hline GUJARAT & 4.8 & 8.0 & 10.3 & 6.6 \\
\hline KARNATAKA & 5.2 & 7.0 & 7.4 & 6.1 \\
\hline MAHARASHTRA & 5.6 & 7.0 & 10.2 & 7.0 \\
\hline TAMILNADU & 5.0 & 6.4 & 8.7 & 6.2 \\
\hline WEST BENGAL & 4.6 & 6.8 & 6.6 & 5.9 \\
\hline INDIA (NDP) & 5.3 & 6.0 & 11.0 & 6.6 \\
\hline
\end{tabular}

Source: Handbook of Statistics on Indian Economy 
Successive droughts from 1983-88 may be the retarding factor for this low growth rate of domestic product during this period. However, the economy of Karnataka could achieve the annual average growth rate of 6 per cent per annum during this period, which is a significant achievement judged against the background of successive droughts ${ }^{1}$.During the I-Phase of liberalisation period all states, with the exception of Andhra Pradesh, recorded growth rate of more than 6.0 per cent and one state Gujarat recorded growth rate of above 8.0 per cent. The software sector growth led by service sector boom since 1990 s has increased the Net State Domestic Product of Karnataka economy during this period. During the II-Phase of liberalisation period (i.e., 2000-01 to 2010-11) not only has the disparity in growth came down also registered high growth rates across the states.

The state of Karnataka registered growth rate of 7.4 per cent during this period which is due to utmost contribution of software sector to the domestic product ${ }^{2}$.For the entire period the growth rate of Net State Domestic Product of Karnataka economy is 6.1 per cent. Thus, the NSDP figures show that the years since 2000 recorded better inclusive growth than the previous periods.

Figure - 1 Compound Growth Rate of Net State Domestic Product of Selected States

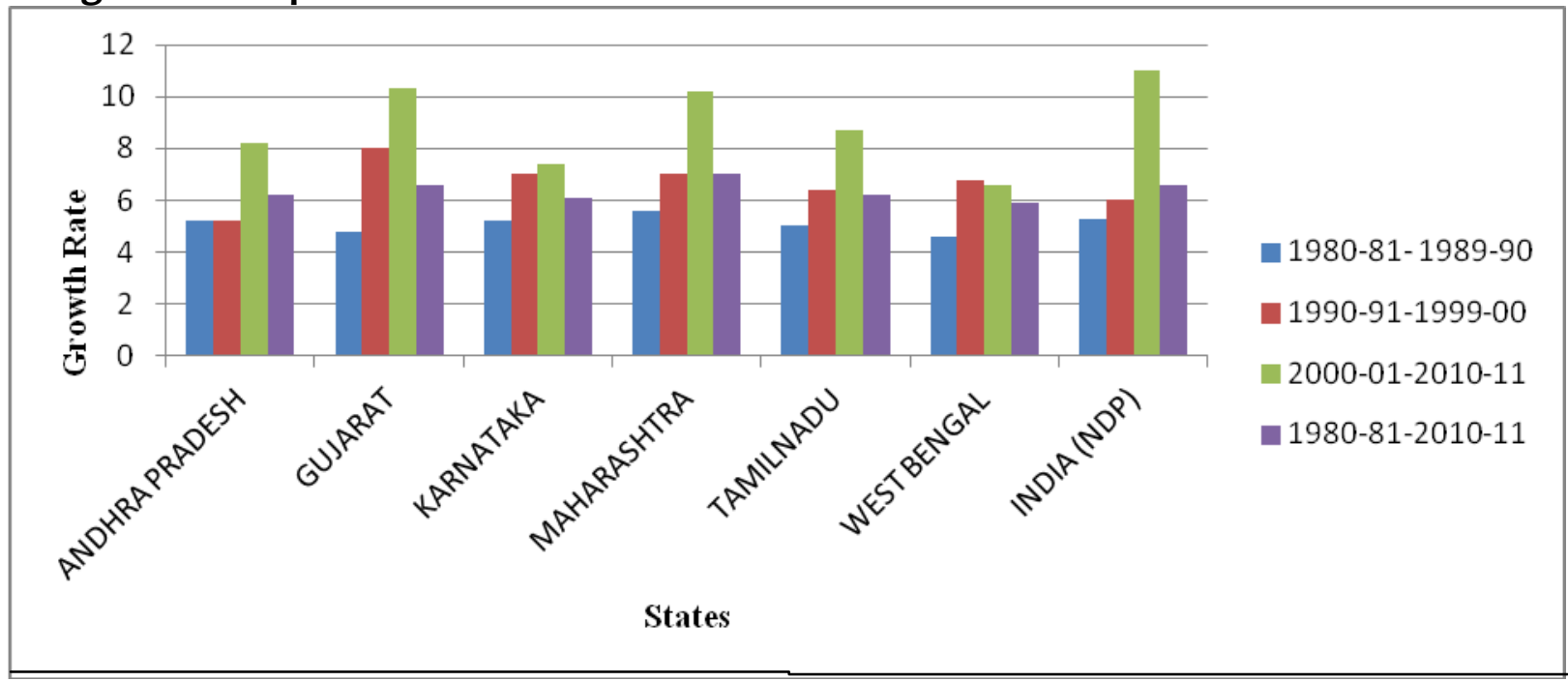

- Sector -wise Growth Rate in Net State Domestic Product of Karnataka

There is a change in the sectoral composition of State income of Karnataka that is over the years as the importance of primary sector has reduced, giving way to the tertiary sector. While this is a natural phenomenon in economic growth, it has to be accompanied by a corresponding shift in employment shares to enable higher levels of income across all sections (Karnataka Growth Story 2011).

${ }^{1}$ G. Thimmaiah (2005)

${ }^{2}$ Karnataka Development Report (2007) 
The contribution of the primary sector, to Gross State Domestic Product (GSDP) which was about 60 per cent during 1960- 61 decreased to 16.22 per cent during 2010-11 and 15.2 per cent during 2011-12. While the secondary sector contributed only 15.2 per cent to GSDP during 1960-61, increased to 28.60 per cent during 2010-11 but decreased to 27.74 per cent during 2011-12. The share of the tertiary sector was 24.8 per cent which has increased to 54.61 per cent in 2010-11 and 56.32 per cent during 2011-12. ${ }^{3}$

\section{- Primary Sector Growth Rate in NSDP of Karnataka}

It can be noted from the table 2 that the primary sector growth rate of Karnataka has been most stagnant and also the least among the three sectors all the times. The I-Phase of liberalisation period had seen 2.0 per cent increase in the growth rate of primary sector of Karnataka economy. At the national level the growth rate increased by 0.3 per cent which is approximately comparable to the growth rate of Karnataka primary sector. Irresponsive policy measures have been blamed for dismal growth rate of primary sector of Karnataka during this period.

Table - 2

Primary Sector Growth Rate in Net State Domestic Product of Karnataka

\begin{tabular}{|c|c|c|}
\hline PERIOD & KARNATAKA & INDIA \\
\hline $1980-81-1989-90$ & 2.0 & 3.0 \\
\hline $1990-91-1999-00$ & 3.9 & 3.3 \\
\hline $2000-01-2010-11$ & 3.4 & 4.6 \\
\hline $1980-81-2010-11$ & 2.4 & 3.1 \\
\hline
\end{tabular}

Source: Handbook of Statistics on Indian Economy

While the State government launched many programmes like Karnataka Agriculture Mission, Farm Mechanisation scheme, Rashtriya Krishi Vikasa Yojana (RKY) and major irrigation projects to enhance the primary sector especially the agriculture sector; the growth rate decreased during the II-Phase of liberalisation period. The growth rate of Indian primary sector increased by 1 per cent during this period. For the period as a whole, the growth rate is low of 2.4 per cent suggesting that the primary sector is not a promising sector for the growth of the economy.

${ }^{3}$ Economic Survey of Karnataka 2011-12 
Figure - 2 Primary Sector Growth Rate in NSDP of Karnataka

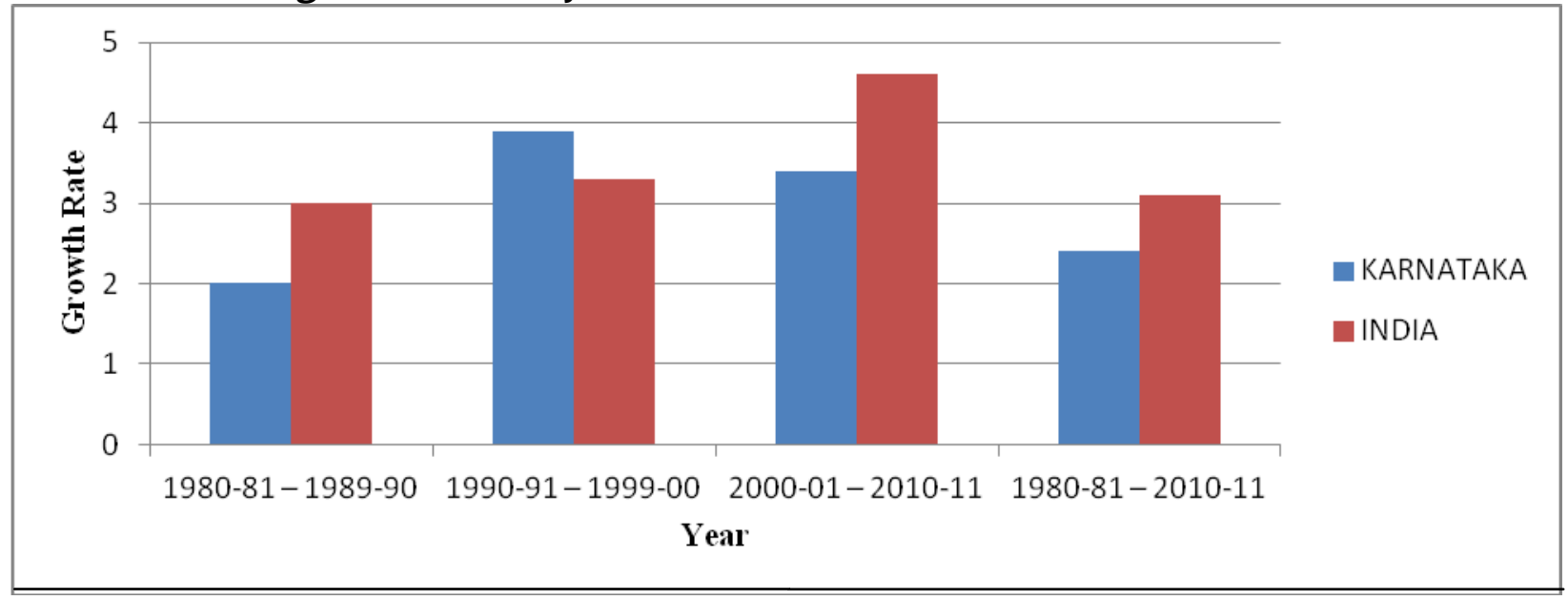

\section{- Secondary Sector Growth Rate in NSDP of Karnataka}

The secondary sector of Karnataka recorded a growth rate of 8.1 per cent during Preliberalisation period (see table.3). However, during Post-liberalisation period for the I-Phase this sector growth rate has decreased to 4.6 per cent for Karnataka and 5.8 per cent for India.

The secondary sector of Karnataka seems to have lost more because of lack of thrust than as a process of economic development during this period. ${ }^{4}$ This trend is reflected at allIndia level where the service sector gained share at the cost of manufacturing sector which is not the case if we take countries like China, Thailand, and Korea (Karnataka Development Report 2007).

Table - 3

Secondary Sector Growth Rate in Net State Domestic Product of Karnataka

\begin{tabular}{|c|c|c|}
\hline PERIOD & KARNATAKA & INDIA \\
\hline $1980-81-1989-90$ & 8.1 & 7.4 \\
\hline $1990-91-1999-00$ & 4.6 & 11.2 \\
\hline $2000-01-2010-11$ & 5.2 & 6.8 \\
\hline $1980-81-2010-11$ & 6.4 & \\
\hline
\end{tabular}

Source: Handbook of Statistics on Indian Economy

Sustained by strong fundamentals, friendly industrial policies and infrastructural support, Karnataka's secondary sector has grown at 5.2 per cent in the II-Phase of

\footnotetext{
${ }^{4}$ Karnataka Development Report (2007)
} 
liberalisation. However this growth rate is lesser than the all-India growth rate. On an average the sector registered a growth rate of 6.4 per cent for the entire period and demonstrating that the secondary sector of the state is moving on the growth trajectory.

Figure-3 Secondary Sector Growth Rate in NSDP of Karnataka

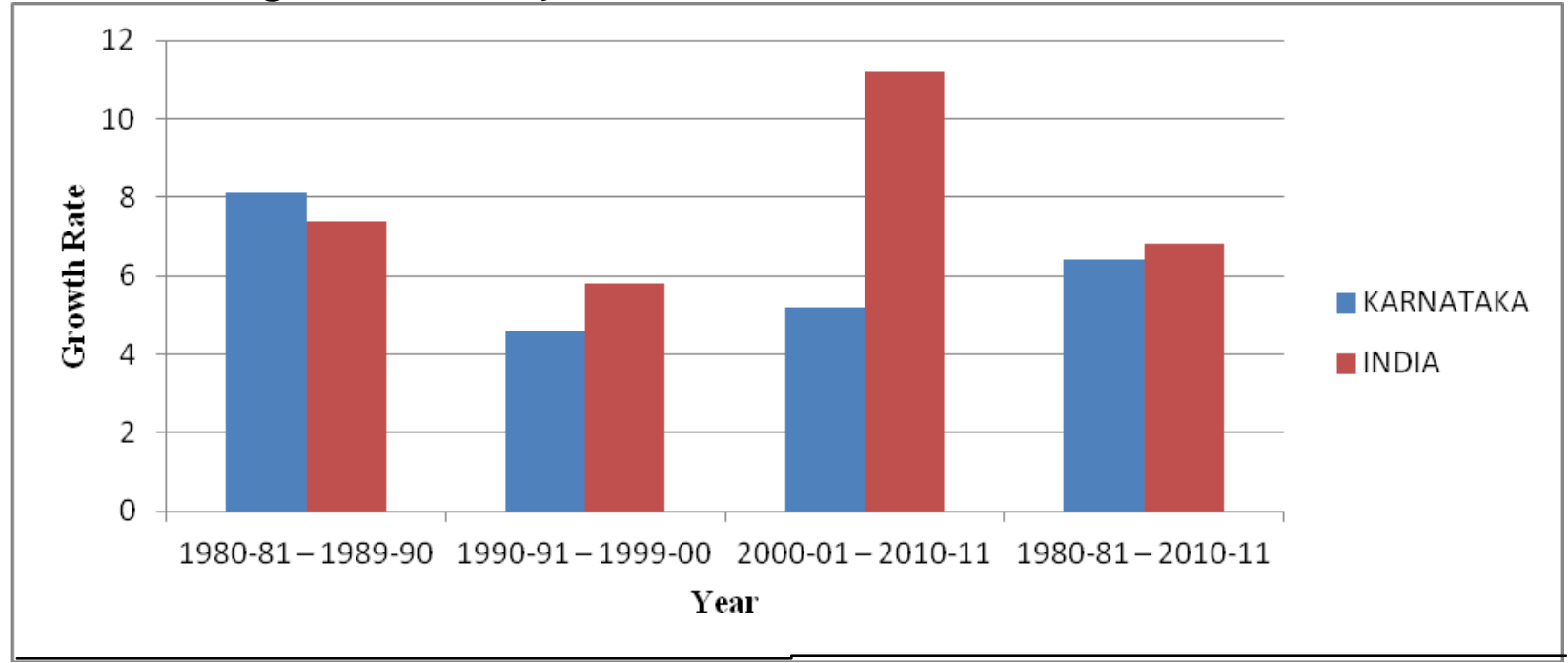

- Tertiary Sector Growth Rate in NSDP of Karnataka

The long term growth rate of tertiary sector of Karnataka and India depicts encouraging trend and followed the pattern of industrialization. As against the two sectors (primary and secondary) the tertiary sector had grown progressively during the I-Phase of libaralisation, in the II-Phase of liberalisation and for the period as a whole for Karnataka and for India.

Table - 4

Tertiary Sector Growth Rate in Net State Domestic Product of Karnataka

\begin{tabular}{|c|c|c|}
\hline PERIOD & KARNATAKA & INDIA \\
\hline $1980-81-1989-90$ & 7.2 & 6.5 \\
\hline $1990-91-1999-00$ & 9.5 & 7.6 \\
\hline $2000-01-2010-11$ & 10.3 & 13.0 \\
\hline $1980-81-2010-11$ & 8.6 & 8.1 \\
\hline
\end{tabular}

Source: Handbook of Statistics on Indian Economy

The growth rate steadily increased from 7.2 per cent during the Pre-liberalisation period to 9.5 per cent during the I-Phase of liberalisation period and to 10.3 per cent during the II-Phase of liberalisation period, recording the highest growth among the three sectors. Emerged as an information technology hub, the state of Karnataka tendered impetus to the growth of overall services. Besides, Karnataka is the leading exporter of software in India. 
The state exported IT services equal to the amount of Rs.70, 375 crores, during 2009-10, the highest in the country.

If the same pace of growth continues for the next ten years, Karnataka would set to become the global services hub of India by $2020^{5}$.

Figure - 4 Tertiary Sector Growth Rate in NSDP of Karnataka

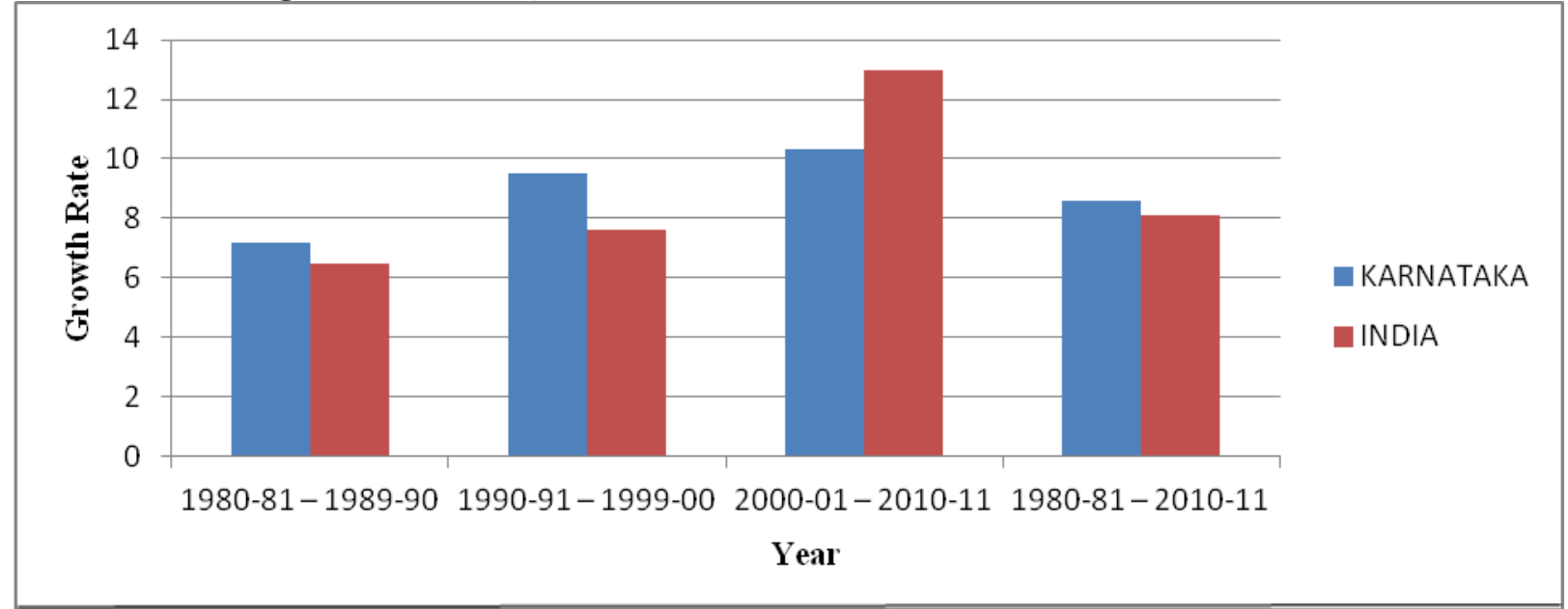

Therefore, it is the service sector which has been the propelling sector for both Karnataka and India since Pre-liberalisation period. The sectoral composition of state domestic product shows that the relative shares of three sectors during the period 1980-81 to 2010-11 (table. 4) that for the entire period tertiary sector has been the major contributor with 55.83 per cent followed by the primary sector with 26.55 per cent. However, the decadal trends demonstrate interesting patterns. In the Pre-liberalisation period, it was the primary sector that dominated 42.47 per cent followed by the tertiary sector with 40.58 per cent.

The picture changed since then. In the I-Phase of liberalisation period the tertiary sector dominated with 47.34 per cent followed by the primary sector by 33.55 per cent. This pattern gained strength in the II-Phase of liberalisation period when the tertiary sector share grew to a high of 63.47 per cent while that of the primary sector declined to 19.39 per cent.

${ }^{5}$ Karnataka Growth Story (2010) 
Table - 5

\begin{tabular}{|c|c|c|c|}
\hline \multicolumn{3}{|c|}{ Relative Shares of Sectors in NSDP of Karnataka } & (Per cent) \\
\hline Year & Primary Sector & $\begin{array}{l}\text { Secondary } \\
\text { Sector }\end{array}$ & Tertiary Sector \\
\hline $1980-81$ to $1989-90$ & 42.47 & 16.94 & 40.58 \\
\hline $1990-91$ to $1999-00$ & 33.55 & 19.10 & $47 \cdot 34$ \\
\hline $2000-01$ to $2010-11$ & 19.39 & 17.12 & 63.47 \\
\hline $1980-81$ to $2010-11$ & 26.55 & 17.61 & 55.83 \\
\hline
\end{tabular}

Source: Handbook of Statistics on Indian Economy

It is disturbing to note that in all the three decades the share of secondary sector has been the lowest and has marginally increased from 16 to 19 per cent. Thus the increase in the share of the tertiary sector has been at the expense of the primary sector. Alternatively one could say that the decline in the share of the primary sector has been offset both by the increase in the share of the tertiary sector and to a smaller extent increase in the share of the secondary sector.

\section{- Summary and Conclusions}

This paper is an enquiry into the trends in the NSDP growth of regional economy of Karnataka for the period 1980-81 to 2010-11. Comparative analysis of compound growth rates of Net State Domestic Product (NSDP) of the selected states in the country reveals that during the I-Phase of liberalisation period the growth rate of Karnataka was highest, while in the last decade the state of Gujarat achieved highest growth rate. However, the growth rate of Karnataka has increased in the II-Phase of liberalisation.

The analysis clearly shows that there is growth prospect in the state of Karnataka. But the relative growth rate of Net State Domestic Product of Karnataka was lower than the growth rate of Net Domestic Product of India during this period.

At the sectoral level the primary sector of the economy faded away during Preliberalisation period. The service sector of the economy occupied the first position in all the three sub-periods and for the entire period (1980-81 to 2010-11). Notwithstanding, the secondary sector of the economy registered good growth rate in the three sub-periods and for the entire study period, it could not compete with the service sector growth rate; by this the service sector became the promising sector for the growth of the economy. Analysis at the national level also reveals the same pattern of the sectoral growth during the study period. 


\section{References}

Ahluwalia, M.S. (2000), "State Level Performance under Economic Reforms in India”, Paper Presented at the Centre for Research on Economic Development and Policy Reform Conference on Indian Economic Prospects Advancing Policy Reform May 2000 Stanford University.

Ahluwalia, M. (2000), "Economic Performance of States in the Post Reform Period", Economic and Political Weekly 5 May: pp.1637-48.

Bhattacharya, V.V. and S. Sakthivel (2001), "Regional Growth and Disparity in India A Comparison of Pre and Post-Reform Decades", Institute of Economic Growth University of Delhi Enclave North Campus.

Bhide, S. et al (2005), "Growth Interdependence among Indian states; An Exploration", Asia Pacific Development Journal Vol.12 No.2.

Economic Survey of Karnataka various issues, "State income, prices and industries", Directorate of Economics and Statistics, Government of Karnataka, India.

Economic Survey of Karnataka 2011-12 Planning, Programme Monitoring \& 20ll-l2 Statistics Department, Government of Karnataka.

Handbook of Statistics on Indian Economy various issues, "National Income Saving and Employment", Reserve Bank of India, Mumbai, India.

India Brand Equity Foundation (2010) "State Economy and Socio Economic Profile of Karnataka", November 2010.

Karnataka Development Report (2007) "Academic Foundation under arrangement with Planning Commission”, Government of India, New Delhi.

Karnataka Growth Story (2010) Department of Industries and Commerce Government of Karnataka.

Kumar. A.C. (2010) "Regional Disparities in Economic Growth: A Case Study of Indian States", Paper Prepared for the $31^{\text {st }}$ General Conference of The International Association for Research in Income and Wealth St. Gallen, Switzerland, August 22-28, 2010.

Kumar. A.T and S. Roy (2011), "Testing the Influence of Different Sectors Contribution to the State Domestic Product Northeastern States of India", Asian Journal of Empirical Research Vol.1 No.2 pp.25-30.

Nayak. P.K et al (2010) “Inclusive Growth and its Regional Dimension”, Reserve Bank of India Occasional Papers Vol. 31, No. 3, winter 2010.

Pillai, M. and N. Shanta (2005), "Long term trends in the growth and structure of the Net State Domestic Product in Kerala", Centre for Development Studies Working Paper 376.

Shiddalingaswami H\& V.K. Raghavendra (2010) "Regional Disparities in Karnataka: A District Level Analysis of Growth and Development", CMDR Monograph Series No. -60 Centre for Multi-Disciplinary Development Research Dharwad-580 004.

Thimmaiah. (2005), "Political Leadership and Economic Development in Karnataka”, Paper Presented at Conference on Development in Karnataka: a Multi-disciplinary Perspective, 06$11-2005$. 